Interfaces

\title{
Performing Surgery: Exploring Gestures in the Operating Theater
}

\section{Christina Lammer}

\section{(2) OpenEdition}

1 Journals

\section{Electronic version}

URL: http://journals.openedition.org/interfaces/600

DOI: ERREUR PDO dans/localdata/www-bin/Core/Core/Db/Db.class.php L.34 : SQLSTATE[HY000]

[2006] MySQL server has gone away

ISSN: 2647-6754

\section{Publisher:}

Université de Bourgogne, Université de Paris, College of the Holy Cross

\section{Printed version}

Date of publication: 21 December 2018

Number of pages: $29-53$

ISSN: 1164-6225

\section{Electronic reference}

Christina Lammer, "Performing Surgery: Exploring Gestures in the Operating Theater", Interfaces [Online], 40 | 2018, Online since 21 December 2018, connection on 05 January 2021. URL: http:// journals.openedition.org/interfaces/600 ; DOI: https://doi.org/10.4000/interfaces.600

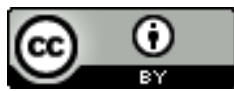

Les contenus de la revue Interfaces sont mis à disposition selon les termes de la Licence Creative Commons Attribution 4.0 International. 


\title{
PERFORMING SURGERY: EXPLORING GESTURES IN THE OPERATING THEATER
}

\author{
Christina Lammer \\ Academy of Fine Arts, Vienna
}

\begin{abstract}
In my arts-based research Performing Surgery (2015-2018) I investigate the gestures of surgeons. For this I attend different types of surgeries with a digital or a $16 \mathrm{~mm}$ camera. This article will present scenes of a $16 \mathrm{~mm}$ series of black and white short movies lasting four minutes with the title Matters of the Heart I-VI of a heart surgery, an operation on the pancreas, an intervention on the blood flow, a surgery of the spine, a reconstruction of the eyelid after facial palsy and a brain surgery. I am particularly interested in the aesthetic aspects of surgery. How do surgeons connect with the bodies of their patients while operating on them? I suggest an approach that brings together art and surgery as parallel stories. Inspired by Jacques Derrida's essay Mémoires d'aveugle. L'autoportrait et autres ruines (1990), by Jean-Luc Nancy's texts L'Intrus (1999) and Le Plaisir au dessin (2009), I develop close-up images of the surgical act. In the recordings of surgeons' hands performing intricate maneuvers during operations I address the humane dimensions of surgery. Thus I regard the medical 'operating theater' as a site of empathy, tenderness, intimacy and sensibility where the harmonious orchestration of hands generates the focus of attention. Since I do not like the manipulations on analogue film material in the editing room, the $16 \mathrm{~mm}$ movies are all done 'in the camera' while watching the surgeries. The idea behind this concept: In terms of the material body of the film - I do not use the knife, only the imaginary one.
\end{abstract}

Résumé: Lors de mon projet de recherche Performing surgery (2015-2018), j'ai étudié les gestes des chirurgiens. Pour ce faire, j'ai assisté à différents types d'opérations chirurgicales enregistrées à l'aide d'une caméra $16 \mathrm{~mm}$ ou numérique. Cet article présente des extraits d'une série $16 \mathrm{~mm}$ en noir et blanc de courts métrages de 4 minutes, intitulée Matters of the Heart I-VI, dans lesquels on voit une opération du cour, une opération sur le pancréas, une intervention sur le système circulatoire, une sur la colonne vertébrale, la reconstruction d'une paupière à la suite d'une paralysie faciale et une opération sur le cerveau. Quelles relations les chirurgiens entretiennent-ils avec le corps de leurs patients pendant l'acte chirurgical? Je propose une approche qui relie art et chirurgie en tant que récits parallèles. Inspirée par l'essai de Jacques Derrida Mémoires d'aveugle. L'autoportrait et autres ruines (1990), et les textes de Jean-Luc Nancy L'Intrus (1999) et Le Plaisir au dessin (2009), je me concentre sur des gros plans de la pratique chirurgicale. En montrant les mains des chirurgiens occupées à leurs tâches minutieuses, je dévoile la dimension humaine de la chirurgie. Ainsi, je montre le bloc opératoire comme un lieu empathique, tendre, intime et sensible, un théâtre où jouent, comme dans un concert harmonieux, les mains sur lesquelles se portent toute l'attention. Comme je n'aime pas manipuler en salle de montage des pellicules analogiques, les films sont tous pris 'in camera' lors de l'observation. L'idée qui préside à cette décision et de ne pas faire de coupure, sinon imaginaire. 


\section{Prologue}

Hands, I see nothing but hands in the surgical operating theater. Hands in white or blue gloves which give them an artificial appearance. "I reflect that these hands belong to men who are men no longer; who are condemned here to be hands only: these hands, instruments. Have they a heart? Of what use is it?" (Pirandello 51f.). Walter Benjamin refers in his comparison of the cameraman with the surgeon in The Work of Art in the Age of Mechanical Reproduction to the novel Shoot! The Notebooks of Serafino Gubbio, Cinematograph Operator (1926) by Luigi Pirandello. Proceeding from Pirandello and Benjamin, I regard surgery and filmmaking as parallel stories. I film operations in order to study the gestures of surgeons for my research. An unusual field of employment in which I don't so much explore the technical performance of surgeons as the gestures and body language of the operators. How do surgeons express themselves with their whole being? How do they encounter the body of the patient in order to treat and heal the person? With the help of instruments: clamps, forceps, electrocautery, scalpel, scissors, aspirator... Each operation goes hand in hand with an injury of the body. This fact alone raises questions that involve sensitive interpersonal relationships. Thus wounding is inscribed in the act of healing.

By means of my analog and digital films, which I have shot as part of a long-term arts-based research work at General Hospital/Medical University Vienna (MUV) in close cooperation with surgeons and patients, I explore the orchestration of manual actions. Therefore I use the camera in the same way as a knife, in order to examine the tissue of the various realities in the operating theater. I choose a sensory approach. Issues of representation of the inside of the body and its organs are illuminated in the same way as the topic of perception of surgery films. Inspired by art historians Aby Warburg's and Georges Didi-Huberman's studies on the pathos formula, I examine surgical operations as gestural proceedings which mirror the relation to the Leib (the human living body) and its organs. Layers become transparent. Sensitivities are sounded out. Surgical practice is compared with analog and digital camera operations, in order to pierce through the fabric of remembrance and embodied knowledge. The modes of imagination - montage as an integral part of knowledge - at the operating and editing tables of surgery and art are revealed.

\section{Film / Body}

In my essay, I make a montage: still images of my operation movies, cut-outs of patients' everyday situations and experiences, pencil sketches and fragments of texts are assembled. Parts melt into each 
other. Descriptions of images - I use the text Bildbeschreibung [Image Description] (1984) by German writer and theater director Heiner Müller as a source of inspiration - are combined with phenomenological concepts. Many types of text are mixed together. Each essay is a form of test arrangement. Photograms ripped out of the filmic flow of movement serve less as illustration than as further layer of content.

I made my first analog film as part of Features - Vienna Face Project (2009-2014) in October 2014. Even though the study was officially finished by that time, I had permission to make a short film of a child's corrective facial operation. The little boy and his parents had known me for a few years. They had participated in my research on facial palsy in the Clinic Department for Plastic and Reconstructive Surgery at MUV. We had become friends and they asked me whether I would like to come to the hospital and accompany the child during the operation. The surgery was performed by renowned Viennese plastic surgeon Manfred Frey, with whom I have been collaborating for over a decade. Everything went well and the boy quickly recovered. My camera operations also worked perfectly. I developed two tapes of three minutes of Super 8 reversal film stock in color myself. I sent another six minutes of black and white recordings to a professional laboratory in Berlin (Germany). A few weeks later, I watched my first Super 8 movies. The projection took place at the Friedl Kubelka School for Independent Film, a rare bastion of analog filmmaking. Two years later, in November 2016, at The Last Machine screening at the Austrian Film Museum, I was among the experimental filmmakers invited to show selected works. Three of the Super 8 rolls of my operation movies were to be presented in the form of a triple projection. However, all three projectors ran hot at the very beginning of the screening. The films were burnt, and the perforation was also damaged. Of course, the Film Museum tried to repair the films, but this was only possible to a limited extent. High quality scans of the damaged material were then made.

In the narrative texture of my little anecdote on facial surgery and the damage of the analog operation movies, essential questions are interwoven: surgery is performed twice, penetrating the material body of reality and an imaginary one. In close dialogue with the Film Museum while restoring the films, I realized that the original Super 8 material - which I developed myself in the darkroom - needed to undergo highly complex digitized treatment procedures in order to bring each single photogram to the quality required for projection. The interaction of analog and digital techniques - for instance, the way I used the scanned data on my computer to re-edit the original movies - made me think of similar transfers inscribed in the practices of surgeons. So I tried to bring these practical issues together with my research interests.ransfers inscribed in the practices of surgeons. So I tried to bring these pr Unlike surgery that penetrates the living realities of organic human beings, an existential dimension is nonexistent in filmic operations. Nevertheless the film camera powerfully affects the viewers' imagination. 


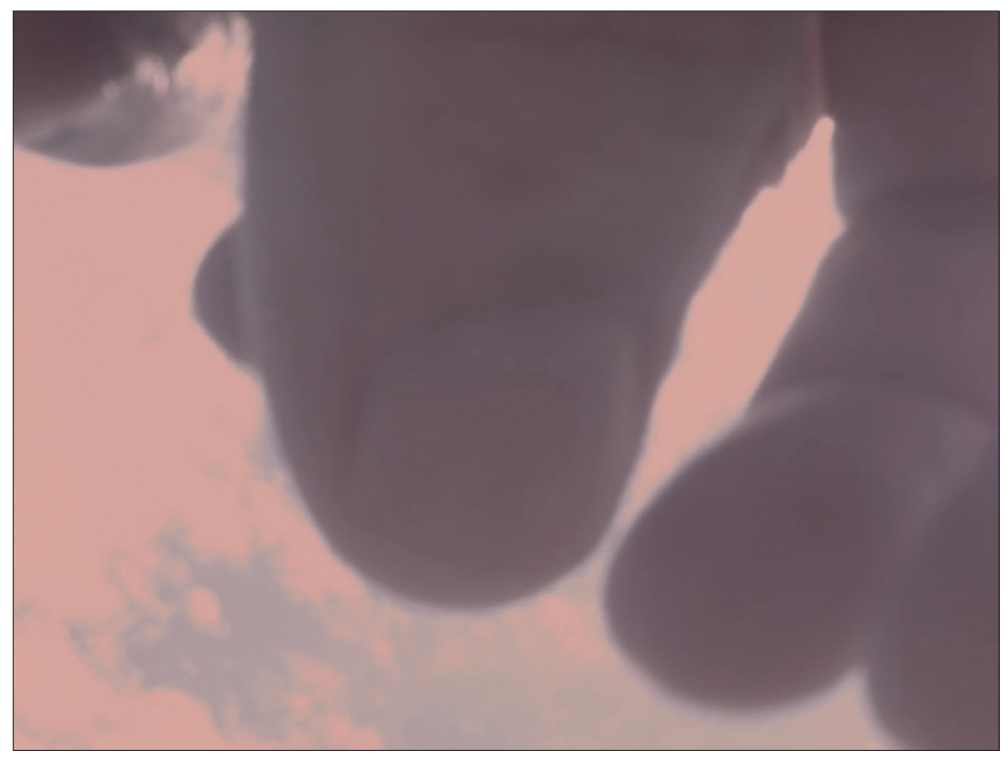

Figure 1: Photogram of the series of short movies Micrograms (2017).

(C) Christina Lammer.

Figure 2: Photogram of the series of $16 \mathrm{~mm}$ black and white short movies Matters of the Heart (2016). (C) Christina Lammer.

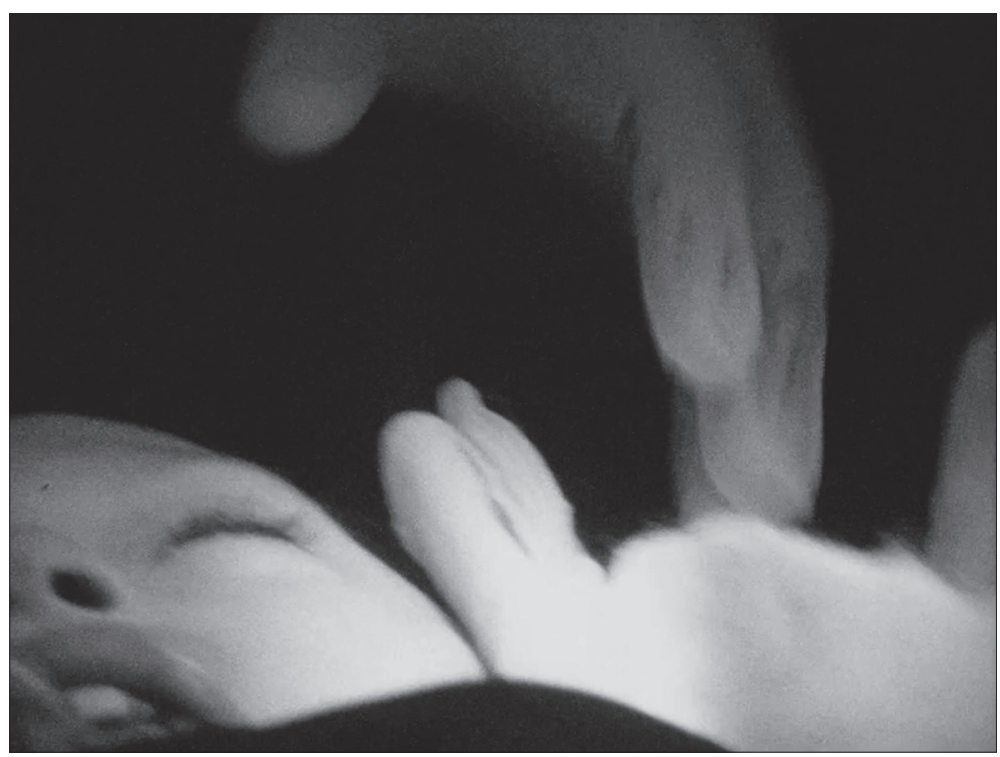


Human tissue and film are both vulnerable substances and they need to be treated and handled with care. Whether in surgery or filmmaking, with the advance of tools and technologies, physical practices are deeply transformed. Currently most surgical interventions are performed with the help of imaging devices. Mobile X-ray and fluoroscopy facilities, ultrasound stations, navigation systems or, for example, endoscopy cameras are used as standard equipment during surgery. Where the eyes of the surgeons are not able to take a closer look, technological aids extend their physical capabilities. The boundaries of body and image become increasingly permeable. Similar changes occur in filmmaking. In her essay Afterward: A Matter of Time (2003) the renowned filmmaker Babette Mangolte writes:

[...] the interaction of digital and film is everywhere inscribed in filmmaking processes today, in cinematography as well as editing and scoring. This constant interaction and transfer of analog to digital and vice versa is changing the relation the filmmaker has with his tools. (262)

She assumes that the tools used affect the filmmaker's subjectivity. Moreover, this constant switch from analog to digital and vice versa transforms the physical contact the filmmaker has with his or her material components. Gestures vary. According to Mangolte:

The first thing you remember about cutting film is the feel and the touch of film emulsion in your hands $[\ldots]$ here you marked with your grease pencil the first frame to cut out, to your splicer $[\ldots]$ you were thinking about that cut, standing up most of the time dancing around your cut. (266)

Dancing around my cut. Investigating the interdependencies between image and body. Thus I regard the intrusion into reality - by hand and technical extensions and expansions - and empathy as corresponding stories.

\section{Hand / Gesture}

My own ethnographic practice mirrors the operations performed by the surgeons who allow me to be there as a witness. They introduce me to their patients, whom I usually see one day before surgery. I develop individual, trustful relationships with both physicians and patients. Before I attend surgeries, with or without a camera, I extensively inform the persons who undergo operations on the following day, explaining the aims of my research and answering possible questions. Patients frequently ask me whether they can see photographs or moving images of the operation. I am certainly happy to share image material in whatever form is expected.

At the time of writing this text, I have already attended about thirty-five surgeries, among them abdominal, brain, heart, orthopedic, plastic and reconstructive, and thoracic operations, with digital 
and analog cameras. Furthermore I have undertaken a variety of visual and sensory ethnographies in interventional radiology between 2000 and 2016. My continuous exchange with physicians of various clinical fields - among them fantastic teachers who have been happy to share their experience with me for almost two decades, as I witnessed the increasing application of medical imaging technologies and digital media - led me to explore surgery and filmmaking as parallel practices.

Heart surgeon Wilfried Wisser (University Clinic of Surgery at MUV), who collaborates on my current arts-based research on gestures, Performing Surgery (2015-2018), explained to me the distinction between "classic open-heart surgery" and minimally invasive procedures in his field: "Minimally invasive heart surgery, I would say this is a rather indistinct term, characterized by the fact that one cannot reach everywhere with the finger". ${ }^{1}$ The question is, "what one needs to see. [...] Haptic feedback," Wisser says, "is the precondition for classic open-heart surgery". Although a paradigm shift "has been at play already for some time, surgery [Chirurgie in German], Chiros, the hand in Greek, is a manual profession". Surgery - as physically performed practice - is undergoing radical change with the increase of technological means. The use of new instruments, devices and materials necessarily leads to a transformation of the performance of surgery.

The interaction of digital (from the Latin for "finger") and analog, the surgeon's hands / body and the patient's organism, is deeply inscribed in the performing procedures. Hence the contact between operator and operated person is fundamentally modified with the application of any technical aid and physical enhancement. While observing operations with my camera, I am frequently not able to recognize what is being done and with what particular aim. During one of the early open-heart surgeries that I filmed, I was astounded that the surgeon held the heart in his hand for what I felt was a few minutes. So heart surgeon Wilfried Wisser explained to me what exactly he had done, while we were watching the video footage: "There I have kept the heart away. Exactly, I introduce my hand and keep the heart away, in order to sew down there, where the cannula is located. It is merely keeping away, what I am doing there - tenderly keeping away". Wisser's credo is to treat tissue as gently as possible: "I do a large share all alone [...] and why am I in the habit of doing it like this? I can be more tender. In order to be able to sew, I keep the tissue as little apart as necessary". If this was done by an assistant, there would be a lot more pull on the tissue.

I combine an ethnographic approach with theoretical considerations based in art and cultural studies. I give particular attention to the dichotomy of body and Leib (the living body). In this regard, I am inspired by phenomenology. French art historian Georges Didi-Huberman writes in his study 


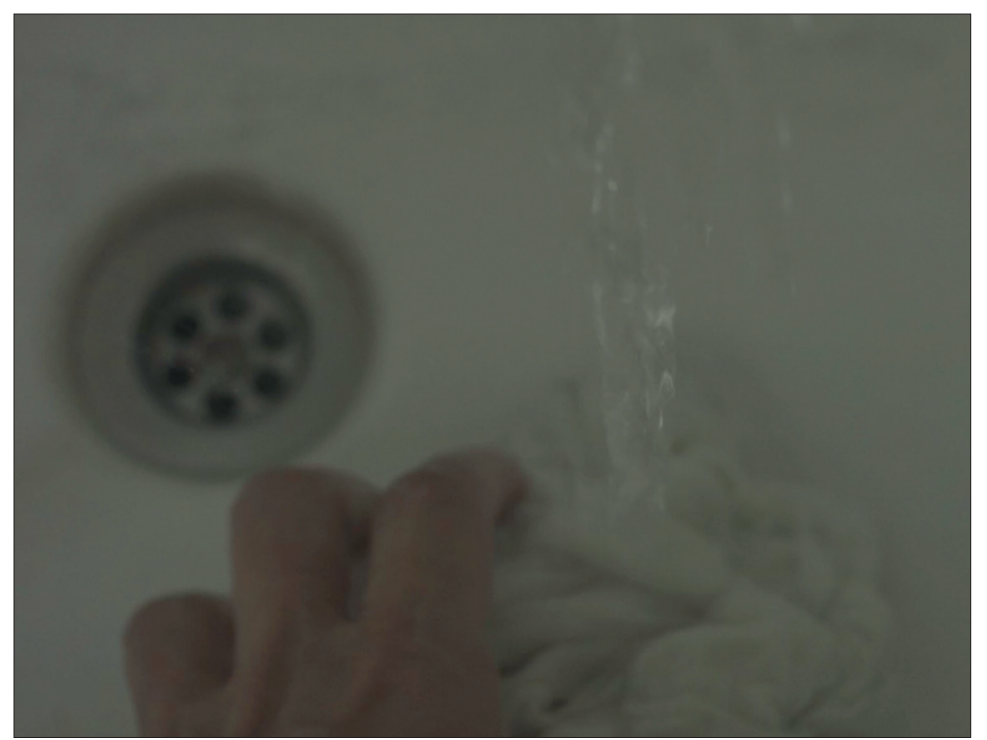

Figure 3: Photogram of the series of short movies Micrograms (2017). C Christina Lammer.

Figure 4: Photogram of the series of $16 \mathrm{~mm}$ black and white short movies Matters of the Heart (2016).

(C) Christina Lammer.

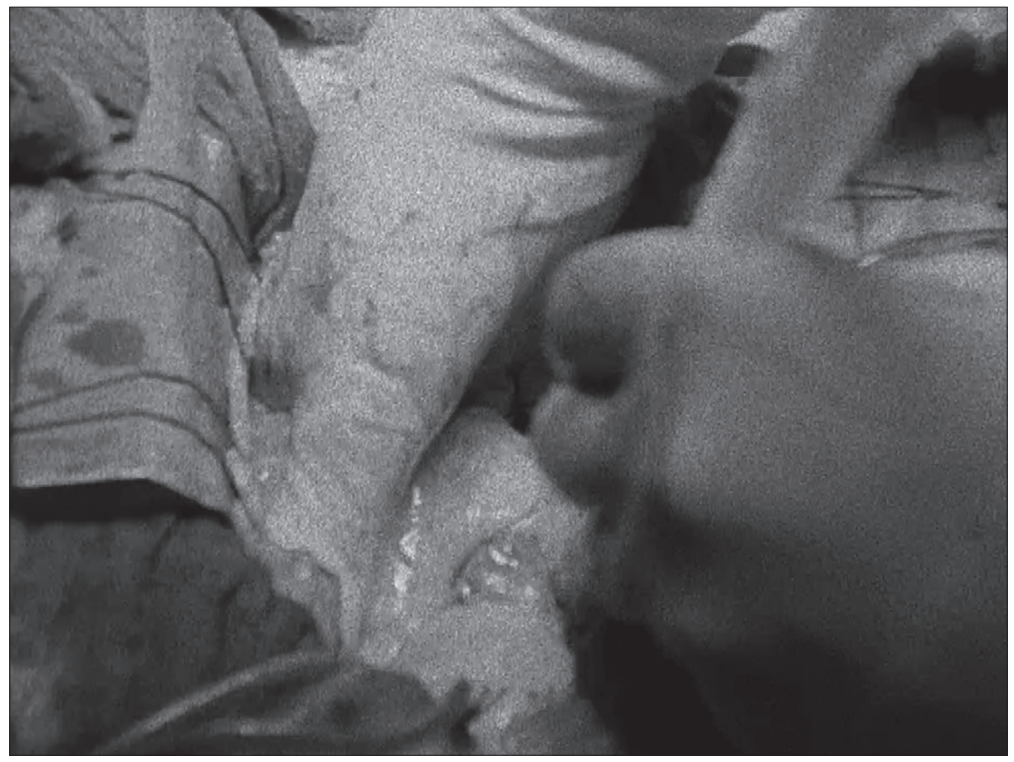


The Surviving Image (published in French 2002) on Aby Warburg that "all that happens inside of the body - actual or represented - is dependent on a particular montage of time" $(2010,248)$. In classic surgery, on the other hand, haptic feedback is essential. In minimally invasive operations the fingers mostly do not reach the scene. Tissue is increasingly treated with instruments. The value of direct touch - manually and with consequently all sensory perception - is changing. Minimally invasive indicated procedures vary in different surgical fields. In heart surgery, according to Wisser, "a kind of camp dispute" takes place. "Some describe those operations as minimally invasive, which do not include a transection of the sternum". By contrast, the use of the heart-lung-machine remains objectively invasive, particularly concerning open-heart surgery: "Without shutting down the heart, I cannot carry out this form of operation". A minimally invasive operation with a small incision does not necessarily mean lower risk. It depends on the overall situation of the patient. In terms of content, I am concerned with how concepts of the human body differ in various surgical disciplines. Does someone who operates on organs in the stomach perceive the interior body in a different way from, for example, an orthopedist or a brain surgeon? Every organ requires specific treatment.

\section{Bone / Work}

Bones involve resistance. Surgeons who operate on the skeleton exercise their physical capacity to the full. For me, these operations are difficult to watch. Paul Klee describes the organism in movement in Pädagogisches Skizzenbuch [Pedagogic Sketch Book] (1965). According to his artistic studies, bones are passive:

Bones work together among themselves to build the skeleton. They require, even in a position of rest, mutual stabilization. Fixed by tendons. The function is subordinated; one can speak of a "structural" of the function. The next "movement organizational step" leads from bone to muscle. The tendon mediates between both. (Klee 17) ${ }^{2}$

As an example, I would like to recount a situation in which I found myself during the first orthopedic operation that I observed - a total endoprosthesis (TEP) of the right hip. I attended the proceedings and found it hard, emotionally and on the level of representation, to film the surgery. I felt that close-up images of operating hands appeared on the viewfinder of my video camera like utterly brutal bloody scenarios. For me, there was hardly any surgical sensitivity to be seen on the images. I could not find access to any aesthetic representability of what I saw at this time. ${ }^{3}$ Today I realize that 
my perspective in those days was the result of my own condition: I need artificial hip joints myself. Recently my left hip has been replaced. ${ }^{4} \mathrm{I}$ am still recovering from the operation. Medical student Bernhard Frank photographed the process. My orthopedic surgeon, Jochen Hofstätter, gave me the femoral head that he had removed from my body, in order to use it for my artistic research. Bone work. In the meantime, I have made colorful transparent resin casts of my bony remnant. Although I found it very hard to watch the earlier hip operation as part of my filmmaking, and I decided to study more sensitive orthopedic surgeries, for instance, interventions on the spine, I am now exploring my own bone and the photo documentation of the procedures in a rather phenomenological arts-based way. For some of the readers, the idea of using one's own body parts to reflect on medical culture and the meaning of the Leib in surgery might be very unsettling. Indeed, my attempts to progress in my method is unusual. However, there are inspiring examples in the world of art: French performance artist Orlan (2004) who transforms her own bodily appearance with the help of plastic surgery (2004); Vienna Actionist Günter Brus, with whom I have written the book Günter Brus: Kleine Narbenlehre (2007) [Small Theory of Scars] about the abdominal operations he had to undergo; English artist Jo Spence, who developed the approach of Photo Therapy (1988 and 1995) in the course of her cancer treatment; to name only a few. In addition, the art historian Tamar Tembeck made an extended study and organized an exhibition at the artist-run center Oboro in Montreal on Auto/Pathographies (2014). The catalogue that came out with the show includes the main contemporary art works in this field. Holding a body part in my hand that had developed its own painful life inside me, is bizarre. On the other hand, it is - or should I rather say was - a part of myself. I was asked at the hospital whether I would like to donate my bone. My response was negative. I preferred to take my femoral head with me. Seventy-five milliliters. Swimming in alcohol for preservation. Formerly located in the center of myself. Cut out.

Cast making is a fascinating method. As a procedure it is all about skin and touch. Reflecting on my own creation of casts of my removed piece of bone, I am interested in the connections between sculpture and surgery. How is the body being reconstructed after the surgical removal of inner structures or how do the operators' hands reform organ functions in a plastic way? Holding a piece of my body in my hand that was still inside me a few weeks ago and has been replaced by a prosthesis, is emotionally demanding and peculiar. I am still in the phase of recovering from surgery. Working on the bone, making colorful resin replicas and preserving the femoral head, is strange. However I enjoy the tacit playfulness that is involved. 


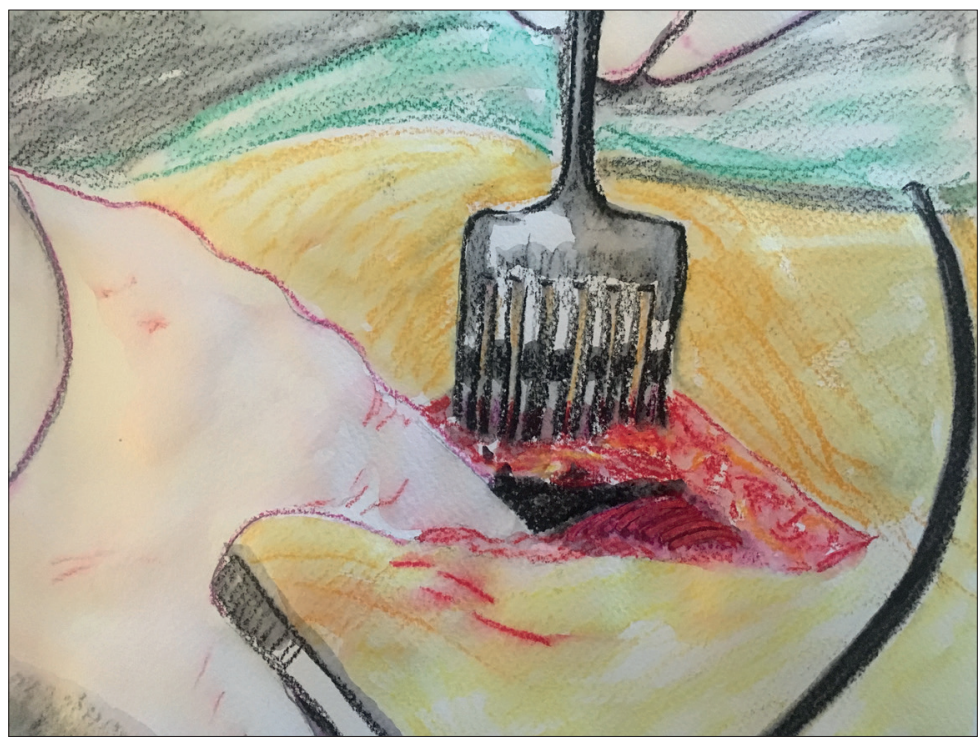

Figure 5: Separating muscles, total endoprosthesis of the hip, graphite and pastel, Bone Work (2017). C Christina Lammer.

Figure 6: Series of resin casts of my femoral head, Bone Work (2017). (C) Christina Lammer.

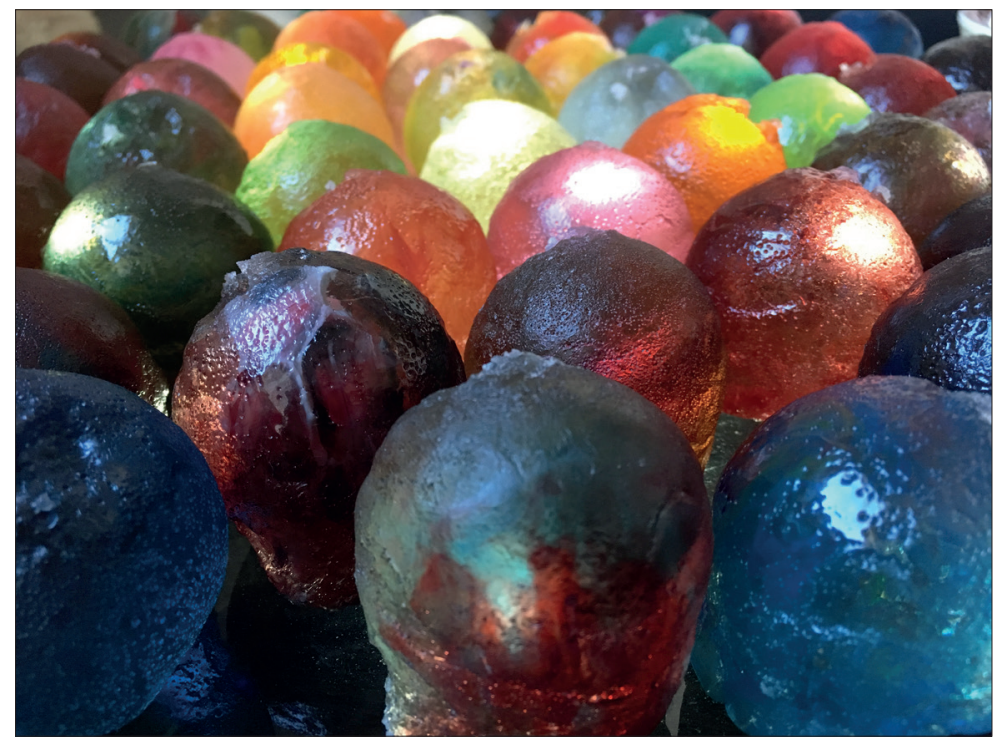




\section{Re / Montage}

Methodologically I try to get as close as possible to the manual practices of surgeons. I study the processes with my camera in the operating theater. The recorded video footage is sighted on the computer. I memorize the processes and appropriate them up to a certain extent. As soon as I have the feeling that I have taken in the course of action and its intrinsic rhythm, I start filming operations with an analog $16 \mathrm{~mm}$ Bolex camera. My earlier research on interventional radiology and minimal invasiveness turned my attention to the increasing application of image-based technologies and digital media in surgery. Particularly the observation of image-led radiological interventions soon made it clear to me that the human body is not only pierced through with the help of a scalpel but in the imagination. I started to follow Benjamin's comparison of camera operator and surgeon more intensively, including this concept into my methodological explorations - as a filmmaker whose own performance gets graspable in the recordings. For this the work with analog film plays an important role.

In a letter to Stan Brakhage, published in On the Camera Arts and Consecutive Matters edited by Bruce Jenkins (2015), the filmmaker and photographer Hollis Frampton wrote on The Act of Seeing with One's Own Eyes (1971), a 16mm film by Brakhage shot in a morgue in Pittsburgh. The autopsy room, according to Frampton, "is a place wherein, inversely, life is cherished, for it exists to affirm that no one of us may die without our knowing exactly why" (158). In the same letter Frampton asked his colleague and friend, "what was to be done in that room, Stan?" (158). A similar question constantly bothers me during my work with the camera at the hospital. What is to be done in that room, for instance, in the operating theater? "And then, later, with the footage?" (158). How do I connect what I see during surgery with the imaginations, experiences and needs of patients whom I visit daily after their operations? How are these complex and contradictory modes of perception artistically representable? One suitable approach for me is analog filmmaking. With a film camera, the generated material still has a physical body. Each single photogram is followed by a black image. The projections of movies breathe. They pulsate vividly. Questions of montage arise in a different way with analog film than with digital video. For my analog operation films, I edit the recordings exclusively in the camera. I start and stop the filming by the push and release of the record button. A three-minute $16 \mathrm{~mm}$ black and white film roll, about thirty meters, is available for each surgery. No matter whether the intervention lasts many hours or only a shorter period of time. This corresponds to my concept of an organic interpretation, intuitive and equally plastic, and similarly developing great proximity with the surgical act:

I think it must have been mostly to stand aside; to "clear out", as much as possible, with the baggage of your own expectations, even, as to what a work of art must look like; and to see, with your own 


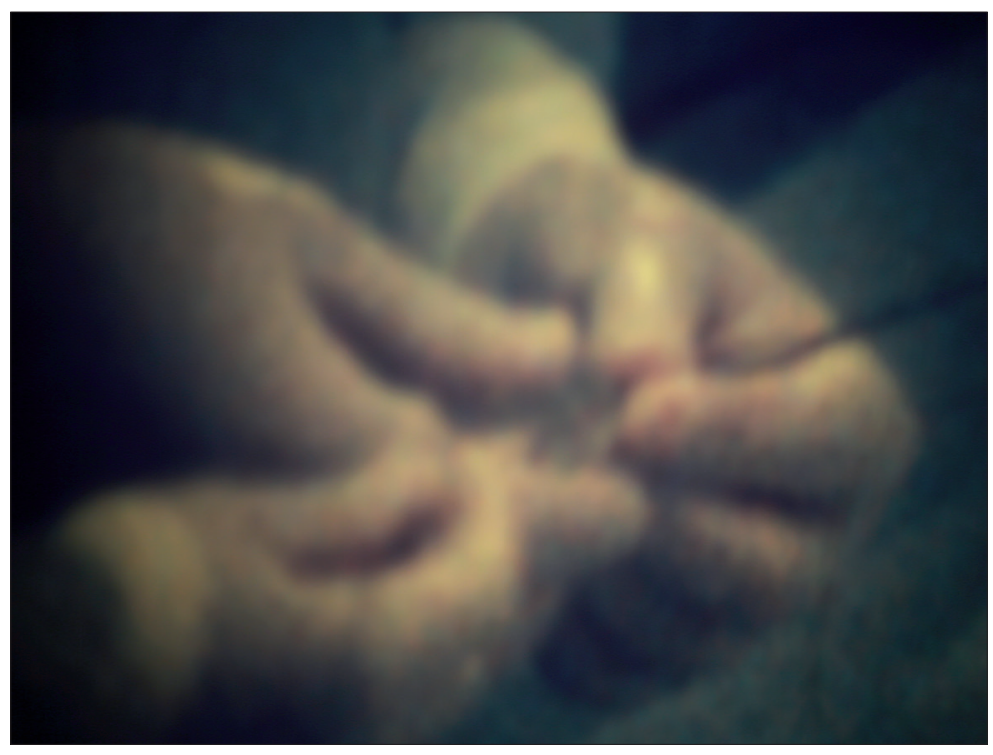

Figure 7: Photogram of a Super 8 short movie, interventional radiology, Blood Flow (2015). C Christina Lammer.

Figure 8: Photogram of a $16 \mathrm{~mm}$ black and white short movie of the series Matters of the Heart (2016). (C) Christina Lammer. 
eyes, what coherence might arise within a universe for which you could decree only the boundaries. (Frampton 158)

In a lecture on film at Hunter College in New York in 1968, Frampton referred to pioneer brain surgeon Harvey Cushing. The physician "asked his apprentices: Why had they taken up medicine? To help the sick. But don't you enjoy cutting flesh and bone? He asked them. I can't teach men who don't enjoy their work" (129). In one of our dialogues, aforementioned artist Günter Brus suggested asking surgeons about their fantasies. What are the driving forces that make them enjoy what they do? Certainly, this is not a question that one can easily put into words.

\section{Camera / Eye}

A sound method needs to be developed in order to go beyond the mere documentation of facts and the execution of interviews. I choose a filmic practice that explores subtle experiences and gestures in the work of surgeons. Frampton describes his camera operations and the interaction between his body and this particular device in the following terms:

A camera is a machine for making footage. It provides me with a third eye, an acutely penetrating extension of my vision. But it is also operated with my hands, with my body, and keeps them busy, so that I amputate one faculty in heightening another. (158)

As I would like to show, there are many connections between the act of filming and performing surgery. A few months ago, I attended two brain surgeries. I shot the first operation with a digital camcorder that I use to study the procedures, and the second one with a Bolex 16mm camera. "Never touch with your hand," the neurosurgeon Thomas Czech, deputy head of the University Clinic of Neurosurgery (MUV), told his assistant. The brain has to be touched with fine instruments. These operations, as an example, are performed with the help of a microscope. The surgeon prepares the operating field, carefully washes head and hair, in order to mark the operating area and the exact location where he would make the incision. He defines the field. The accomplished surgeon opens the skull with the help of a fine drill. The device produces a strange familiar sound that vaguely resembles those used at the dentist's. Carefully the scalp is being opened. Until then the surgeon feels his way to the interior of the head with the naked eye. Subsequently he extends his vision with a neurosurgery microscope that at the same time works as a camera, and allows the viewer to recognize the tiniest structures in the brain in order to operate on them. Enlarged two-dimensional high-definition images are made visible on several monitors in the operating theater. Everyone in the room can follow the operation. Recordings in high resolution are made for educational purposes. Occasionally an oversized finger shows up on 


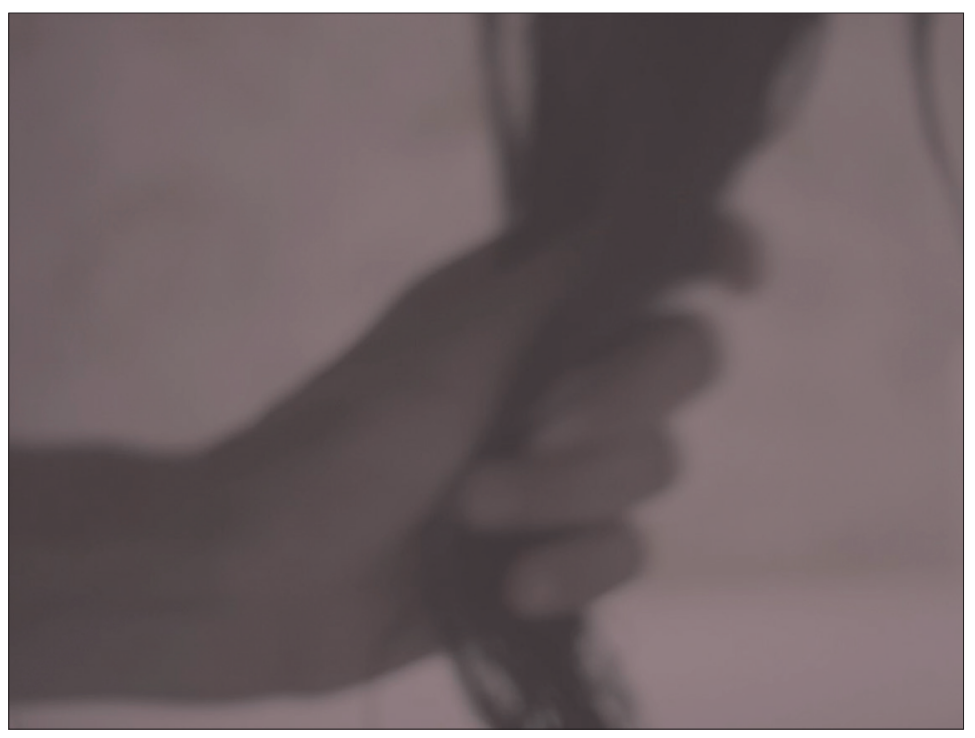

Figure 9: Photogram of the series of short movies Micrograms (2017). C Christina Lammer.

Figure 10: Photogram of the $16 \mathrm{~mm}$ black and white short movie of the series Matters of the Heart (2017). (C) Christina Lammer.

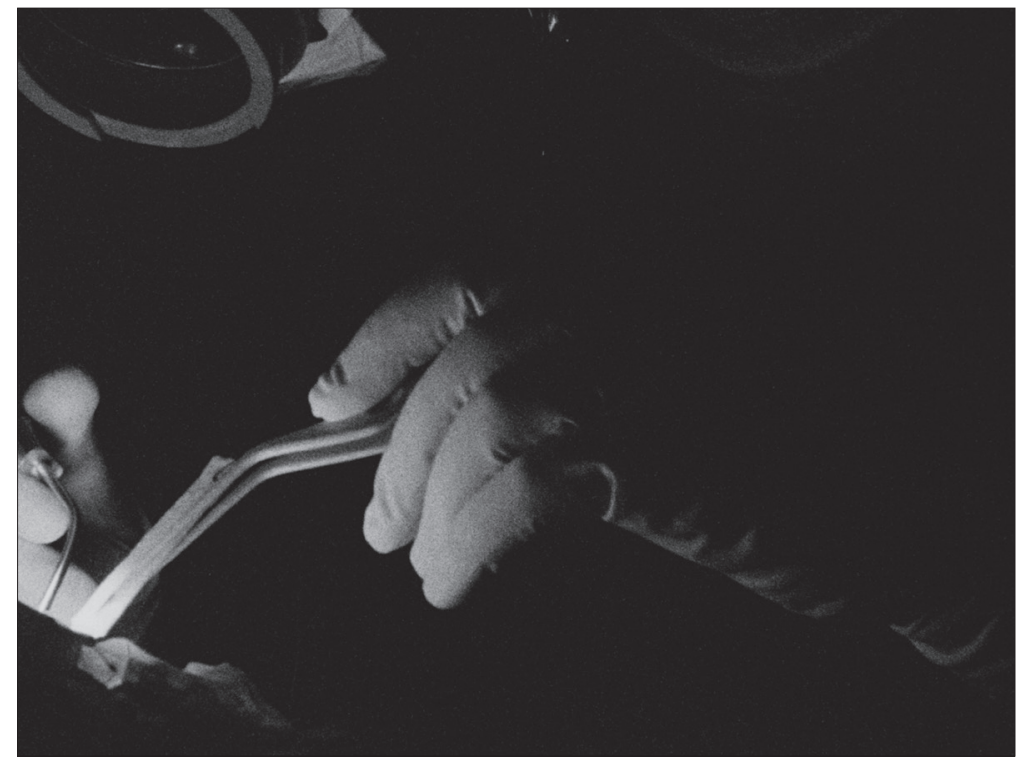


the images, which reminds me as a non-medic of the size ratios. The act of seeing and operating in this particular field of surgery, as in other surgical disciplines, demands full body use, although the physical proceedings of the operators and the orchestration of hands vary in different surgical fields.

As an example, I can describe an operation in neurosurgery: the surgeon's body is at once confined and enhanced. The microscope is a machine to enlarge the tiniest organic structures, extending the natural field of vision that we can capture with our eyes. As with any camera, a highly mediated view is provided, piercing through the fabric of the brain, penetrating reality and creating high-quality images of the procedures. To that effect, the eyes of the surgeons are tightly connected with the oculars of the device. The delicate movements of the hands are guided by image operations. The neurosurgeon sits in a specially developed operating chair designed for this area of work. Most of the lights in the room are dimmed or completely turned off in order to watch images on monitors. Neurosurgery is an area where imaging technologies and navigation systems play an immensely important role. The constant transfer from digital, electronic data calculated on the basis of the binary number system 0 and 1, to analog, graspable by hands, and vice versa changes the relation the surgeon has with the body s/ he operates on. A computerized reality, seen through sensors, coexists with a touchable physical body.

\section{You / I}

Operations with electronic devices, the handling of material components and instruments and the ability to sense structures in the body's interior co-exist and interact. In his logic of science and cultural studies, the philosopher Ernst Cassirer differentiates the thing and expressive perception (37-59). He envisages three dimensions:

The dimension of the physical being, the representational, the personally expressed, are governing and necessary for all that is not mere "effect" and that belongs in this sense not only to "nature" but also to "culture". The elimination of one of these dimensions, the inclusion into one singular level of consideration, always results in a flat image of culture, and does not reveal its actual depth. (46)

As a solution to this dilemma, Cassirer suggests a phenomenological analysis: "We need to try to understand each kind of language $[. .$.$] in its peculiarity, without reservation and epistemological$ dogma; we need to determine how much it contributes to the building up of a "common world"' (46). Regarding the operating hands, which I examine in surgery, the operations include expressive power. "I" and "you" belong by virtue to both spheres, the world of "I" and the one of "you" (45). In the act of healing in surgery, both modes of perception - thing and expression - are inseparably connected with each other. Although during the intervention the perception of the body (as thing) comes to the fore, the 


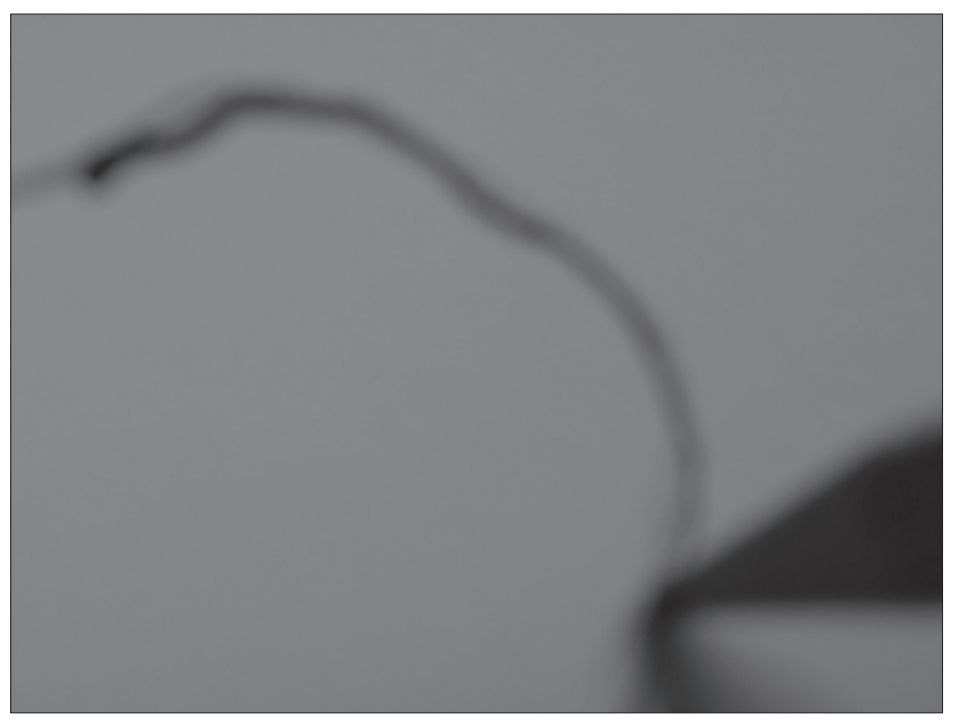

Figure 12: Photogram of video recordings of a corrective face surgery (2017). (c) Christina Lammer.

Figure 11: Photogram of the series of short movies Bone Work (2017). (c) Christina Lammer.

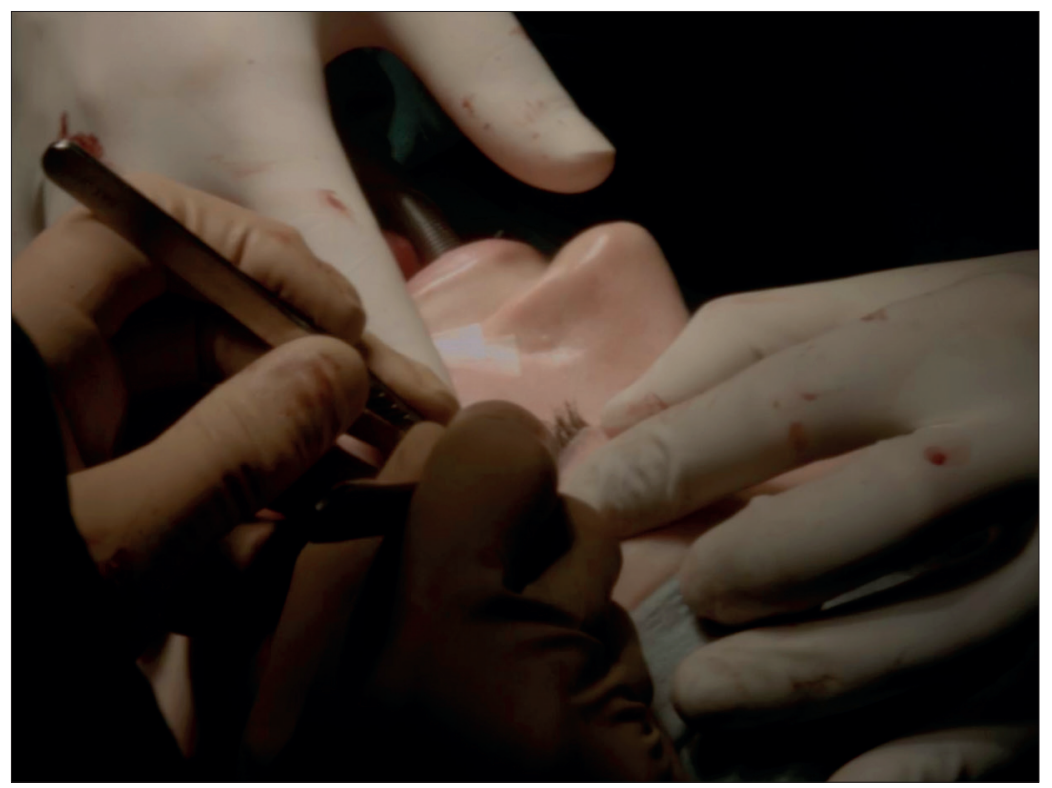


relation of "I" and "you" remains. The sick put themselves in the hands of doctors, who, in the decisive moment, pierce through the reality of the body entrusted to them. Surgeons need to make decisions for the person who is unconscious during the operation, which is likely to have a great influence on the lives of these human beings. How do digital calculations, which accompany physical actions, change the interaction of "I" and "you"? Movement, gesture, touch, the entire choreography and body language of the surgical performance, take another shape as soon as "technological fingers" are involved. This does not only affect surgery. There are parallels to be made in the practice of shooting film.

Nurtured by Heiner Müller's Bildbeschreibung, I will continue my essay with the interpretation of Deus Ex (1971), a 16mm movie made by Stan Brakhage at a hospital in Pittsburgh. The film was quite influential for my own film work. Brakhage combines scenes at the clinic with elements of plants; sterile aesthetics with the vital sensuality of a human being; the view out of the window on the cloudy sky and trees with dark empty rooms inside. Familiar images: dream and nightmare at the same time. The sensitive and nevertheless extraneous handwriting of the film artist gets under the skin. He purposely scratched the film material. By hand, Stan Brakhage signed in the title, the opening and after the credits on the filmstrip. Description as inscription, traces of expression. At the beginning of Deus Ex, a grey curtain is opened. Part of a bed appears. Shadows on a tiled floor. The blurred contours of a person. Feet in white shoes. And a curtain again. The scenes unfold out of a cloudy darkness. Suddenly a clean white cloth fills the frame. Fragments of a body. Sewing hands. The head of a nurse.

\section{Blind / Operations}

Close-up images. Blurred. A woman in a wheelchair. Piled up towels. An empty corridor. A head resting on a cushion. Backlit shots. Images are paraphrased through language. Performance Studies scholar and playwright Theresia Birkenhauer writes in an article on Müller's Bildbeschreibung:

The image in language is therefore for each new reader / listener other. In this constellation, there is no absolute relation of archetype and afterimage, of original and copy; the point from which the image has been painted, the description has been written, the text has been read, is not to be detected. (106)

Through language, imagination is being set in motion. "In the movement of writing" a space is opened, "in which image and viewer are undistinguishable. It is opened with the image that unfolds with the eyes of language" (105). Coming back to Brakhage's film, the imagination is overwritten by my subjective impressions. In his essay Memoirs of the Blind, Jacques Derrida compares drawing with surgery. He reflects on what "happens when one writes without seeing? [...] It is as if a lidless eye had opened at the tip of the fingers, as if one eye too many had just grown right next to the nail, a single 
eye, the eye of a cyclops or one-eyed man" (3). A lamp or prosthesis. Being reminded of Brakhage's handwriting, "the movement of these letters, of what this finger-eye inscribes, is thus sketched out within me" (3). Back to Deus Ex: Wrappings. A woman with a cigarette stands in front of a window. Again shot with backlight. Dark shades. A preemie kicks in an incubator. Machines. A hook. Cables. Entering a long corridor with lamps on the ceiling. A nightgown covers parts of a body. I love these details and uncanny structures. They chime with my own memories. Wrapped in a bandage, a hand gesticulates. A patient wakes up after an operation. Still intubated. The legs of someone walking are mirrored on a shiny floor. A man sits in his bed. White coats. Metal. Skin. Looking out of the window. A thick black spiral cable develops its own life. Tree branches. From there the camera eye glances in the operating suite. Close-up of a flower in backlight. Preparing for surgery. Sterile clothes. Using surgical instruments. Bloody gloves. Very short shots. Operating field. Wound. In Deus Ex the camera view continuously oscillates between an interior and an exterior space of perception. Textures are revealed. Some scenes are recorded in slow motion. Flicker.

A black stain is becoming a plant with leaves and bushy flowers. Water pipes. Lights. Stan Brakhage's name scribbled by hand. His signature. Referring to paintings and drawings of the graphic collection at the Louvre in Paris, Derrida compares the work of the artist, with the gesture of a surgeon:

He shows this movement, this touching or examination, with the assured gesture of a surgeon. But a surgeon who does not look at his hands any more than a blind man does. He turns his eyes neither towards what he holds between his hands, the vertical or oblique point of a scalpel, staff or pencil, nor towards what lies beneath his hands, the body, the scarified skin, the ground or surface of inscription. (60)

Intuitive proceedings. Tracing. I assemble associations and while my fingers glide over the keyboard of the computer, various threads of content are interwoven. Sketchy images of "a world proliferating with lacunae, with singular images which, placed together in a montage, will encourage readability, an effect of knowledge" (Didi-Huberman 2008, 167). Following on the descriptions of the analog hospital movie Deus Ex by Stan Brakhage, I continue with one of the recent operation films that I have shot in abdominal surgery. I will now discuss digital close-up images of a pancreatic head resection. In the course of these complex interventions lasting several hours, large parts of the pancreas are removed in order to treat cancer. After the removal of tumorous tissue the organic structures and vessels are reconstructed. The functions of the body are rebuilt. For the first time I solely filmed out of hand, without any tripod or monopod. The anesthetist allowed me to stay near the head of the patient. Thus I could follow the event at close range. I glanced over a green sterile cloth that was draped around a metal pole directly into the depth of the body, although I could hardly move from my privileged 


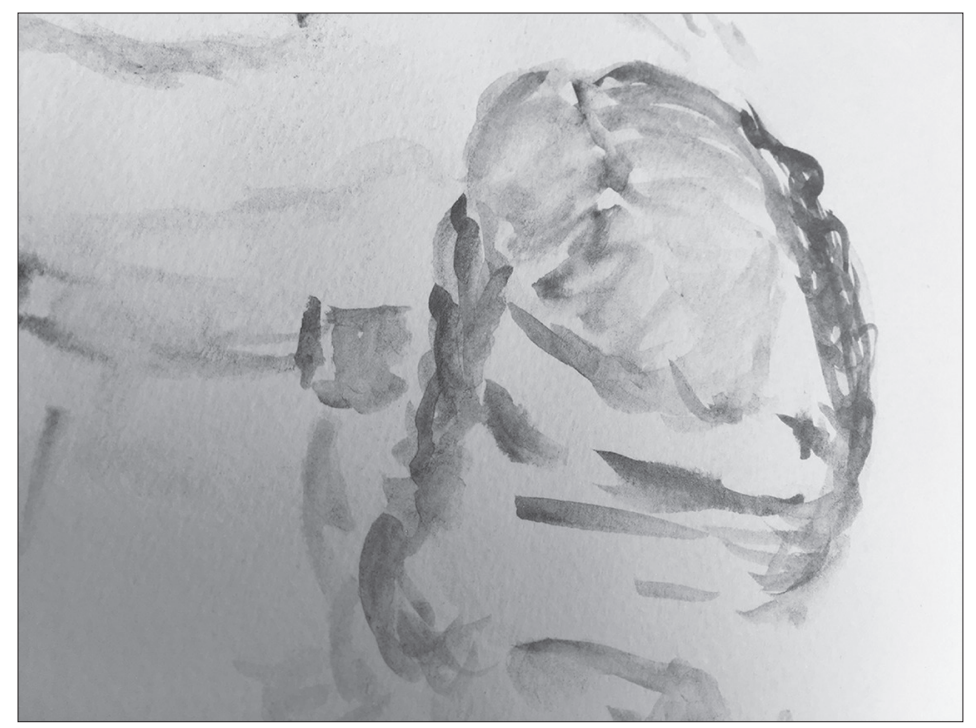

Figure 13: Graphite sketch, brain surgery on a girl (2016). (C) Christina Lammer.

Figure 14: Photogram of the short movie Percept (2017).

(C) Christina Lammer.

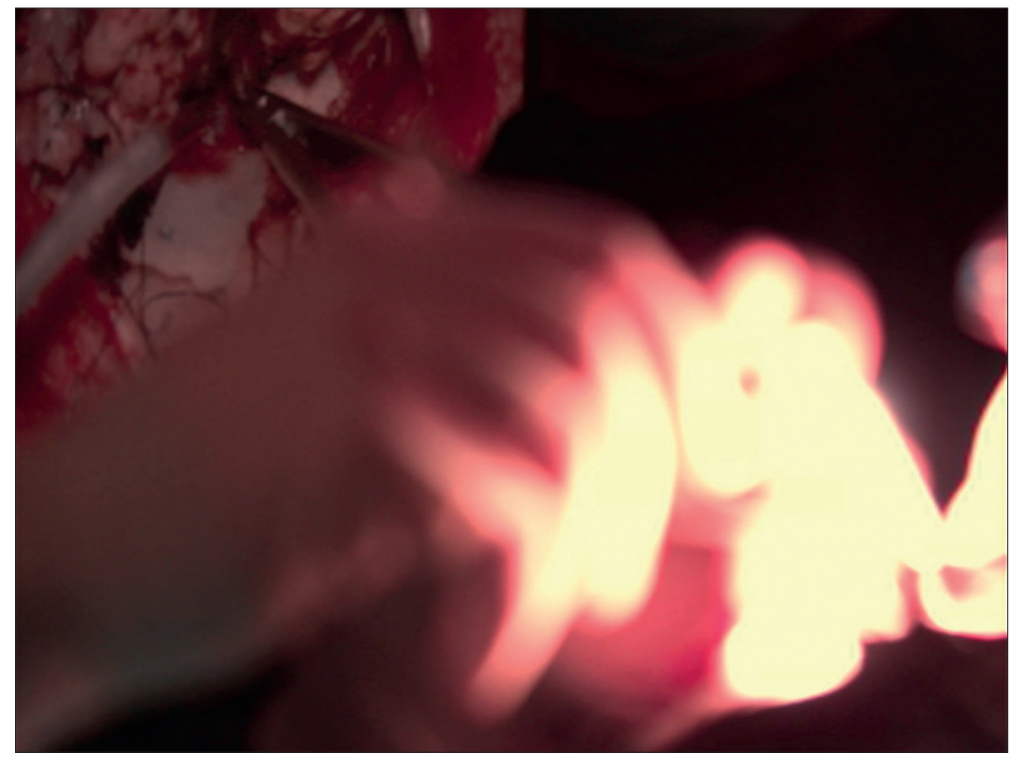


position. The green curtain reached up to my shoulders. Partly on tiptoes and with the camera overhead I pressed the release button after regular intervals without being able to see the viewfinder. Filming from the gut. My attention was fully focused on the operation and less on the process of recording. Close to the surgical proceedings. The filmed images are partially blurred and strangely moving. A certain abstractness arises. The texture of the organic interior seems to merge with the gestures of the operators, material components and instruments. Remontage. Arranging details which create imaginary connections with each other in an uncanny way.

\section{Gut / Feeling}

Looking out of the window. The sun is shining and on the $21^{\text {st }}$ floor of the clinic the hospitalized patients overlook the entire city. What a wonderful view. I visit an older man whose pancreas was operated on a few days before. Carefully he gets out of bed and follows me to the window. "Do you know what you are looking at?" 5 He is breathing heavily. I answer with conviction, "this is the Wienerwald". Incorrect. We laugh. "Over there is the church at Steinhof". The golden dome shines in the sunlight. He tells me about his hometown and shows me where exactly he lives in Vienna. He misses his small garden. Eventually he may go home in a few days. The man is still waiting for the histology results. Most likely he will need chemotherapy. The day before, another surgery had been considered. The drainage transported a dark, nearly black liquid into the transparent pouch that was inspected and changed at regular intervals. A suture in the interior may have given way. However the situation looked much better after a few hours. The content of the bag became lightly greenish. No more talk about a further operation.

Medical images are rarely obvious. I regularly attend interdisciplinary Tumor Board (TB) meetings. Histories of cancer patients are discussed among surgeons, radiologists, oncologists, internal specialists, pathologists and radiation therapists. As an example I will describe the situation of the Pancreas-TB at MUV. The renowned abdominal surgeon Martin Schindl coordinates this TB, in which pancreatic diseases are discussed in the group once a week. Issues for singular cases could read as follows: "Histological verified pancreas carcinoma, completion of neo-adjuvant chemo therapy, image comparison requested, surgery possible?"6

These rounds take place in a darkened seminar room where diagnostic scans are presented in the form of a screening. The radiologist scrolls through loads of MRI, CT, PET, fluoroscopy and 
endoscopy images. Even pathological samples are analyzed in the group. As a non-medic, I can hardly recognize significant structures. Although I can discern organs and bones, I am still not able to identify pathological or cancerous features. However, for the experts the readability of these images is not always self-evident either. Thus, decisions - for instance, whether surgery is possible or not - are the result of highly collaborative processes among the members of the group. Existentially precarious situations for patients are mirrored in some of the medical records given by doctors. Frequently such narratives go beyond mere medical case discussions. Interpersonal dimensions and the broad spectrum of suffering are perceived by the participants. Along with the image-led approach into the human body, dependent on the disciplinary expertise and beside the necessary emotional distance, many issues, notions and findings are at stake. "The questioning of the image," according to art historian Georges Didi-Huberman, "does not only concern visual examination, what has been called the 'scopic drive': it requires the constant intersection of events, speech, and writing" (2012 93f). Decisions need to be, Didi-Huberman argues in Images in Spite of All, "patiently developed" (94). By attempting to "read" and understand this pool of image data - by intersecting experiences, contemporary and retrospective findings by members of the group - the interpretation will always be fragile, though nevertheless a screen to the truth. Embodied knowledge is transmitted by the operator in the act of performing surgery on a human body. A surgeon reads an image in another way than, for example, his or her colleagues in radiology or oncology. Lidless eyes open at the fingertips, referring to Jacques Derrida's notion of blindness. One literally feels inside the body for the pathology with the help of these technologically generated and quite cinematic visualizations.

Skin. Hands, nothing but hands. Incision. A red line is drawn on the belly, ending in a curve around the navel. Layers are loosened from each other with the help of thermocautery. Structures inside the body are revealed. A smell of burnt flesh is in the air. Smoke clouds rise. Blue cloths are pushed into the abdomen. Blurred images. Close-ups. Filmed with a $75 \mathrm{~mm}$ lens, fixed focal length. The incision gets increasingly bigger. The boundaries are fuzzy, fingers, tissue, material components and instruments visibly melting into each other. Ivory-white hand movements, blue draperies, silver shiny hooks, green operation gowns, the color of skin and yellow organs predominate. Finger ballet. Sewing. The camera feels its way. It is in my hands, however partially eluding my view. I stretch my arms and press the record button. My view is different from the camera perspective. At arm's length. Close contact. Detached from phases of silent contemplation. The head of the patient is located at the level of my lower abdomen. I gently stroke her forehead with my free hand from time to time. The anesthetist watches me sympathetically. Sometimes the assistant surgeon leans his upper body towards us. The surgical drape bulges out so that there is almost no space between him and the woman's face. I push the physician a little bit aside. He immediately reacts and changes his position. All this happens 


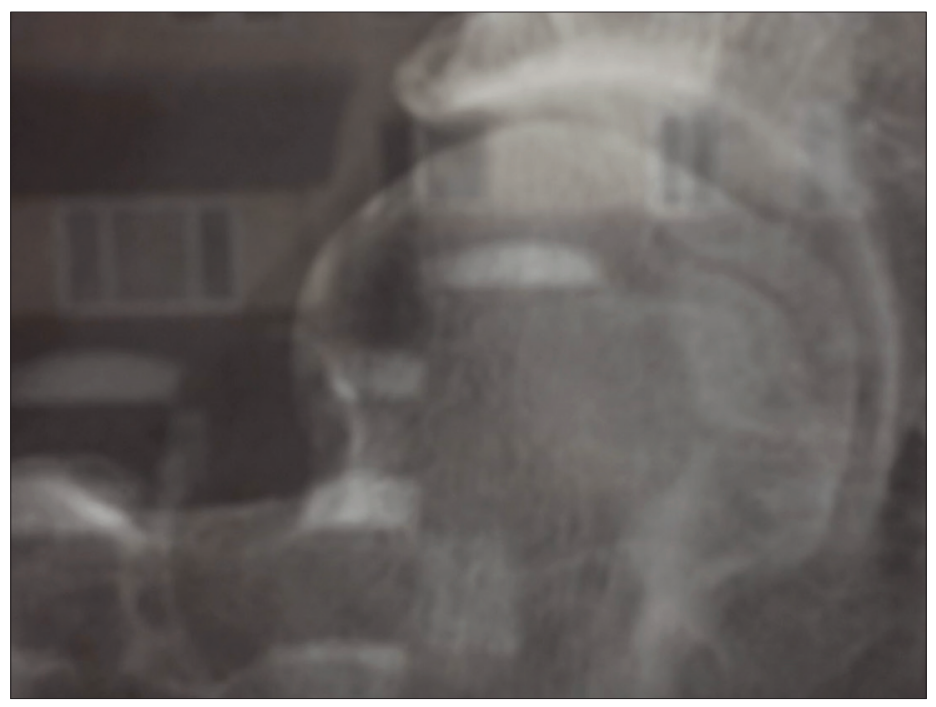

Figure 15: Photogram of the series of short movies Micrograms, 2017. (C) Christina Lammer.

Figure 16: Photogram of the series of $16 \mathrm{~mm}$ black and white short movies Matters of the Heart, 2016.

(c) Christina Lammer.

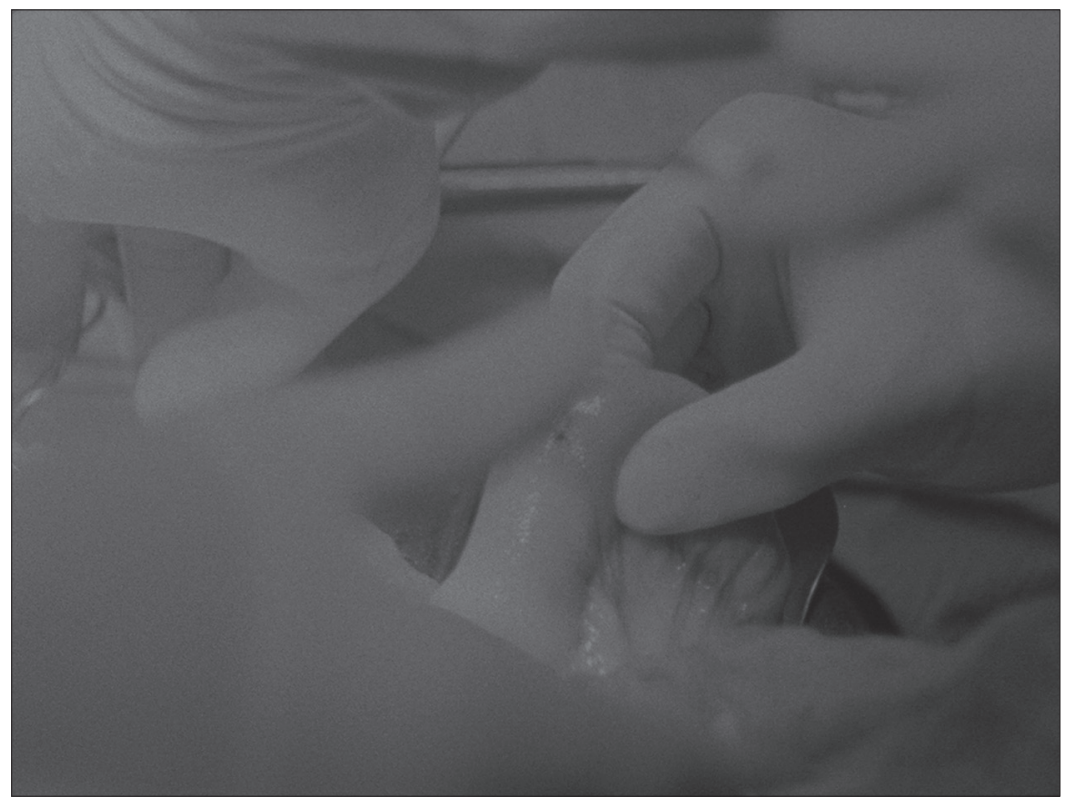


without words. Belongs to the usual course of an operation. The operators align their postures at the surgical field. Gestures in the operating theater lead me on and around. They touch me. Possibly I am unsettled by them or at least tuned thoughtfully. They reassure me or I get hopelessly irritated. Visceral surgeon Martin Schindl delicately treats an intestinal loop with needle and thread. He moves his hands and body with tender responsiveness on the supple and obviously sensitive belly organs. Being gentle on the fabric. All this is gestural.

\section{Epilogue}

A specific body language is accompanied by an intuitive elasticity that goes far beyond mere skillfulness. Nowadays I look for this vitality that one can find in virtually any everyday activity. In the artistic context, for instance, in dance, experience is referred to as flow. Being in the flow. "The heart pumps (active). Blood is being moved (passive). The lung receives and continues to change, participates (medial). The heart pumps. Blood is being set in motion again and returns to the heart, its point of departure" (Klee 22). The heart surgeon Wilfried Wisser initially drew my attention to the term flow. He uses the expression when he enjoys himself in the course of performing surgery. If an operation goes well - in the sense that there is a good atmosphere in the operating theater, the team working together in a smooth and concentrated way - he can be there from the very beginning of the operation, to mention only a few aspects that can play a role for the creation of a flow. As a matter of fact, such experiences can be found in the most common proceedings. Gestures come from within. "Work as human activity (genesis) is either productive or receptive: movement" (Klee 23). In my arts-based research, I explore the world of surgery by means of artistic operations with the camera in order to reveal the intrinsic liveliness that comes with these gestures. I argue that bodily or rather leibliche modes of expression are inscribed in any human activity. A montage unfolds. "Productively it lies in the manual limit of the creator (he solely has two hands)" (23). The hand of the plastic surgeon touches the face of the child. Dancing fingers in the bright sunlight. The heart in the gentle hand of the operator gets associated with the hand-wash in the sink. "Receptively it is dependent on the limitation of the receiving eye. The demarcation of the eye is the impossibility to see an even very small measured area sharp" (23). Hand operations. Drawing hands. Single-eye microscope. Unbraiding a girl's pigtails. Washing hair. Just before a brain operation. Monitor images of the interior of the head. "The eye needs to graze the area, grazing and sharpening one section after the other, giving one after the other for remembrance to the brain, which collects and accumulates the impressions" (23). The hands of surgeons are sewing inside the abdomen. The sensitivity of the tissue is mirrored in the soft light of the black and white recordings. The X-ray images of a hip are juxtaposed with an urban landscape. View out of the window. Superimposed on the inner existence. Flow experience or enjoying one's activity arises from an inner 
liveliness that operates and expresses itself individually in a variety of ways. Intervention. Touching the organic realities beneath the skin. A co-existence is constituted, a relationship that is inseparably connected with empathic gestures. Whether the organs in the abdomen are operated on with the aid of fine instruments and small incisions or an intervention is led with the help of a microscope, surgery requires a sensitive feeling, an intrinsic relation between operator and treated body.

\section{Acknowledgements:}

I would like to thank surgeons Thomas Czech, Manfred Frey, Martin Schindl, Reinhard Windhager and Wilfried Wisser, their teams and the clinics at the Medical University Vienna (MUV) for their invaluable cooperation! All my thanks go to the patients who allowed me to film their surgeries. Thank you for your trust. And, last but not least, I would like to thank my orthopedic surgeon Jochen Hofstätter for supporting my artistic work and his student Bernhard Frank for making fantastic photographs in the course of my hip surgery. Performing Surgery (2015-2018) is funded by the Austrian Science Fund (FWF). Thank you!

Go to http://www.corporealities.org/ or http://labocine.com/to watch the films.

\section{Works Cited}

BENJAMIN, Walter. Das Kunstwerk im Zeitalter seiner technischen Reproduzierbarkeit. 1963. Frankfurt am Main: Edition Suhrkamp, 2015.

BIRKENHAUER, Theresia. "Bild - Beschreibung. Das Auge der Sprache". Ed. Ulrike Hass. Heiner Müller: Bildbeschreibung. Ende der Vorstellung. Eggersdorf: Theater der Zeit, Recherchen 29, 2005. 93-111.

CASSIRER, Ernst. Zur Logik der Kulturwissenschaften. Hamburg: Felix Meiner Verlag, 2011.

CROS, Caroline, Laurent LE BON and Vivian REHBERG (eds.). Orlan: Carnal Art. Paris: Flammarion, 2004. Transl. Deke Dusinberre.

DERRIDA, Jacques. Memoirs of the Blind. 1990. Chicago and London: University of Chicago Press, 1993.

DIDI-HUBERMAN, Georges. 1997. Ähnlichkeit und Berührung. Köln: Dumont, 1999.

—. Das Nachleben der Bilder. 2002. Frankfurt am Main: Suhrkamp, 2010.

—. Images in Spite of All. 2008. Chicago and London: University of Chicago Press, 2012. 
DIDI-HUBERMAN, Georges (ed.). L'Empreinte. Paris: Centre Georges Pompidou, 1997. Exhibition catalogue.

FRAMPTON, Hollis. "Untitled from A Visitation to Insomnia". 2009. Ed. Bruce Jenkins. On the Camera Arts and Consecutive Matters: The Writings of Hollis Frampton. Cambridge, MA, and London: The MIT Press, 2015. Page 122.

HASS, Ulrike (ed.). Heiner Müller: Bildbeschreibung. Ende der Vorstellung. Eggersdorf: Theater der Zeit, Recherchen 29, 2005.

KLEE, Paul. Pädagogisches Skizzenbuch. 1965. Berlin: Gebr. Mann Verlag, 1997/2003.

LAMMER, Christina. "Features (2010-2014)". Corporealities (2005-2009). URL: http://www.corporealities. org/features-2010-2014/ (page accessed 23 ${ }^{\text {rd }}$ August 2018).

—. Günter Brus: Kleine Narbenlehre. Eine Leibgeschichte in drei Akten. Wien: Löcker Verlag, 2007.

—. CORPOrealities. Wien: Löcker Verlag, 2007.

MANGOLTE, Babette. "Afterward: A Matter of Time”. Eds. Richard Allen and Malcolm Turvey. Camera Obscura, Camera Lucida: Essays in honor of Annette Michelson. Amsterdam: Amsterdam University Press, 2003. 261-274.

MÜLLER, Heiner. "Bildbeschreibung”. Ed. Ulrike Hass. Bildbeschreibung. Ende der Vorstellung. Eggersdorf: Theater der Zeit, Recherchen 29, 2005. 10-17.

PIRANDELLO, Luigi. Shoot! The Notebooks of Serafino Gubbio, Cinematograph Operator. 1915. Milton Keynes: Dodo Press, 2010.

SPENCE, Jo. Cultural Sniping. New York: Routledge, 1995.

—. Putting Myself in the Picture. Seattle: The Real Comet Press, 1988.

TEMBECK, Tamar (ed.). Auto/Pathographies. Alma: Sagamie Édition d'Art, 2014.

\section{Films Cited}

Brakhage, Stan (dir.). Deus Ex, 1971 (USA, 35 minutes).

—. The Act of Seeing with One's Own Eyes, 1971 (USA, 32 minutes). 